\title{
Effects of different dietary vitamin A levels in the red shrimp Pleoticus muelleri (Bate, 1888) (Decapoda, Solenoceridae)
}

\author{
Efecto de diferentes niveles de vitamina A en la dieta del langostino \\ Pleoticus muelleri (Bate, 1888) (Decapoda, Solenoceridae) \\ Analía V. Fernández Gimenez ${ }^{1,2}$, Ana C. Díaz ${ }^{1,3}$, Susana M. Velurtas ${ }^{1}$, \\ Ana M. Petriella ${ }^{1,2}$ and Jorge L. Fenucci ${ }^{1,2}$
${ }^{1}$ Departamento de Ciencias Marinas, Facultad de Ciencias Exactas y Naturales, Universidad Nacional de Mar del Plata, Argentina
${ }^{2}$ Consejo Nacional de Investigaciones Cientificas y Técnicas CONICET, Buenos Aires, Argentina
${ }^{3}$ Comisión de Investigaciones Científicas CIC. Funes 3350, B7602AYL, Mar del Plata, Argentina
acdiaz@mdp.edu.ar

\begin{abstract}
Resumen.- Se evaluó el crecimiento, la supervivencia, morfología celular, estructura y la actividad enzimática de proteinasas del hepatopáncreas del langostino Pleoticus muelleri (Bate, 1888). Se realizó un experimento con juveniles en acuarios durante 6 semanas. Los animales fueron alimentados con dietas semipurificadas con diferentes niveles de vitamina A $\left(140,160\right.$ y $180 \mathrm{mg}$ vitamina $\mathrm{A} \mathrm{kg}^{-1}$ dieta). No hubo diferencias significativas en supervivencia e incremento en peso en los distintos tratamientos en las condiciones de trabajo. El estudio histológico permitió visualizar cambios estructurales en el hepatopáncreas de los individuos alimentados con diferentes niveles de vitamina A. Los organismos del tratamiento de $180 \mathrm{mg} \mathrm{kg}^{-1}$ presentaron una morfología funcional normal, en cambio en los alimentados con las otras dietas se observó un deterioro del órgano que denota signos de desnutrición, tales como: hiperplasia e hipertrofia celular, desorganización del tejido y retracción celular. La mayor actividad de proteinasas se registró en los tratamientos de 140 y $160 \mathrm{mg} \mathrm{kg}^{-1}$ y se observó una disminución significativa en el de $180 \mathrm{mg} \mathrm{kg}^{-1}$. Se puede concluir que el nivel recomendado de vitamina A en la dieta para $P$. muelleri es de $180 \mathrm{mg} \mathrm{kg}^{-1} \mathrm{y}$ que en situaciones de desnutrición el hepatopáncreas presenta importantes cambios estructurales y alteración en la actividad de las proteasas.
\end{abstract}

Palabras clave: Crustacea, crecimiento, hepatopáncreas, nutrición, cultivo

\begin{abstract}
Growth, survival, changes in the hepatopancreatic cell morphology, and digestive proteinase activity were evaluated in the red shrimp Pleoticus muelleri (Bate, 1888). A six-week trial was carried out with juveniles of $P$. muelleri in aquaria. Animals were fed with semi-purified diets with different levels of vitamin A (140, 160 and $180 \mathrm{mg}$ vitamin $\mathrm{A} \mathrm{kg}^{-1}$ diet $)$. No differences in survival and weight gain of shrimp were observed among any of the dietary treatments under the experimental conditions. Histological results yielded differences among treatments. In shrimp fed $180 \mathrm{mg} \mathrm{kg}^{-1}$, the functional morphology of the hepatopancreas was normal. Consistent changes with signs of malnourishment, such as cellular hyperplasia and hypertrophy, disorganized tissue, and shrinkage of cells, were evident in the organ of shrimp fed the other diets. The highest proteinase activity was recorded with diets 140 and $160 \mathrm{mg} \mathrm{kg}^{-1}$ and a significant decrease was observed with $180 \mathrm{mg} \mathrm{kg}^{-1}$. It can be stated that optimal level of vitamin A in diets for P. muelleri is $180 \mathrm{mg} \mathrm{kg}^{-1}$ and under malnourishment the hepatopancreas presents structural changes and alterations in protease activity.
\end{abstract}

Key words: Crustacea, growth, hepatopancreas, nutrition, culture

\section{Introduction}

The red shrimp Pleoticus muelleri (Bate, 1888) is the most abundant penaeid species in the Argentine Sea and is distributed from 20 to $50^{\circ} \mathrm{S}$ (Boschi 1986). As the availability of the commercial catches undergoes yearly fluctuations (FAO), it is important to establish the feasibility of culturing this species in order to maintain a continuous supply to the market. This shrimp has acquired great interest on account of its potential use in culture in temperate areas. Juveniles of 3 grams of mean weight reaches 20 grams in 5 months reared in 3000-L tanks
(Fenucci et al. 1990). One of the main obstacles to culture this penaeid species is the inadequate knowledge of their nutritional requirements.

Several studies have revealed that fat-soluble vitamins A, D, E, and $\mathrm{K}$ are essential in most animals for a good health and to perform different life functions, such as growth, development, maintenance, and reproduction (He et al. 1992). Many studies have evaluated the dietary essentiality of vitamin A for penaeids (He et al. 1992, Liang \& Ji 1998, Reddy et al. 1999a, 1999b). 
Vitamin A is essential for normal structure and function of eyes and gills in fishes (Poston 1986), due to its involvement in mucopolysaccharide metabolism, visual pigments, and in general the maintenance of differentiated epithelia in various physiological systems (Tacon 1991). It is also involved in calcium transport across some membranes, in reproduction and embryonic development, and in cellular and sub-cellular membrane integrity (Akiyama et al. 1991). Vitamin A is concentrated in the eyes of crustaceans and is not distributed throughout the body, as in vertebrates. This localized distribution suggests that the role of this vitamin in crustaceans may be more limited than in vertebrates (Conklin 1997). Although these facts, recent findings in crustaceans points out the importance of retinoids as bioactive molecules resides to a large degree on their conversion to retinoic acid, that are involved in the activation of nuclear receptors of retinoids and in body development and function (LiñánCabello et al. 2002).

The hepatopancreas is the largest organ in decapod crustaceans and has many biological functions, including synthesis and secretion of digestive enzymes, absorption of digested products, maintenance of mineral reserves and organic substances, lipid and carbohydrate metabolism, distribution of stored reserves during the molt cycle, and catabolism of some organic compounds (Ceccaldi 1997). The histology of P. muelleri hepatopancreas in intermolt is morphologically similar to that described for other Decapoda (Fig. 1) (Cuartas et al. 2002).

Digestion has been one of the most intensely studied areas of shrimp nutrition with emphasis on the enzymes. In several cases, the assays were carried out only with the hepatopancreas; in others the whole gut was used. The activity of proteinases during different molting stages in hepatopancreas of wild P. muelleri was studied by Fernández-Gimenez et al. (2001). This knowledge can eventually be used as a reference for the culture of the species.

This study evaluated the optimum levels of vitamin A in diets for Pleoticus muelleri, using histological changes of hepatopancreas cells, and digestive enzymes activity as indicators of vitamin deficiency.

\section{Materials and methods}

A six-week feeding trial was conducted to determine the effect of supplemental dietary vitamin A on weight gain, survival, hepatopancreas cell morphology, and proteinase activity. The experimental system consisted of 150-L glass aquaria, with under gravel filter as described by Boschi (1972). The juveniles were reared from hatchery-raised postlarvae (wild broodstock from Mar del Plata,

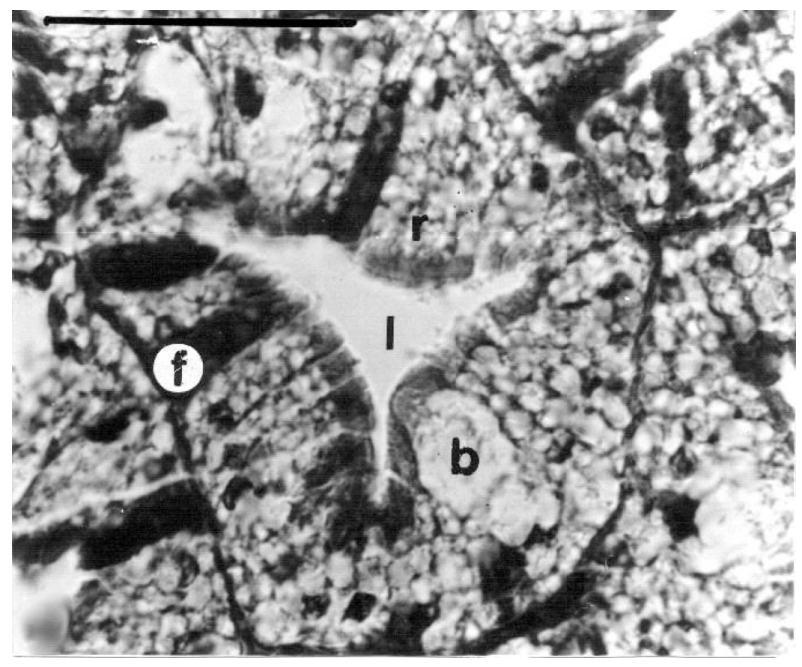

Figure 1

Hepatopancreas of wild $P$. muelleri: transverse section through a tubule showing the types of epithelial cells. Note the narrow lumen and the scarce intertubular space. b: cell B, f: cell F, r: cell R, l: lumen. $B a r=25 \mu \mathrm{m}$

Hepatopáncreas de individuos silvestres de P. muelleri: corte transversal de un túbulo que muestra los distintos tipos de células epiteliales. Se observa el estrechamiento del lumen y el escaso espacio intertubular. b: célula $B$, f: célula $F$, r: célula $R, 1$ : lumen. Barra $=25 \mu \mathrm{m}$

Argentine). Nauplii were transferred to 3.5 ton upwelling tanks and maintained at $21^{\circ} \mathrm{C}\left( \pm 1^{\circ} \mathrm{C}\right)$. Larvae were reared on a diet of algae (Chaetoceros gracilis, Tetraselmis chuii) and Artemia persimilis nauplii. During the larviculture, the animals were fed microencapsulated feeds of different particle size: protozoea $1(0.30 \mu \mathrm{m})$, protozoea 2 and 3 (30 to $90 \mu \mathrm{m}$ ), mysis and early postlarvae (80 to $150 \mu \mathrm{m}$ ) (Mallo et al. 1999). One hundred and five shrimp weighing $1 \mathrm{~g}$ mean weight were randomly distributed in aquaria at a density of 7 animals aquarium ${ }^{-1}$. Three replicate aquaria were assigned for each treatment. Prior to initiation of the feeding trial, shrimp were fed diet without vitamin A supplementation for 7 days. This period was used to deplete the tissue vitamin A reserve.

Three levels (140, 160, and $180 \mathrm{mg}$ Rovimix A 500 $\mathrm{kg}^{-1}$ diet) [500,000 IU vitamin $\mathrm{A} \mathrm{g}^{-1}$ Rovimix A 500] (the use of this vitamin does not implicate an endorsement of this product), were added to a semi-purified diet. Dietary ingredients (Table 1) were mixed and diets were prepared by using the cold extrusion process, then oven-dried at $45^{\circ} \mathrm{C}$ for $24 \mathrm{~h}$ (Fenucci \& Zein Eldin 1976). One control group was fed with fresh squid mantle (Illex argentinus Castellanos, 1960) and the other with a vitamin-free semipurified diet. 
Table 1

Ingredient composition of standard semipurified diets

Composición de las dietas semipurificadas

\begin{tabular}{|c|c|}
\hline Ingredient & $\mathrm{g} \mathrm{kg}^{-1}$ \\
\hline Casein, vitamin-free $^{\mathrm{a}}$ & 375 \\
\hline Protein squid mantle ( $85.5 \%$ crude protein) & 25 \\
\hline Gelatin & 120 \\
\hline Manioc starch & 220 \\
\hline Cellulose & 100 \\
\hline Free fatty acids & 70 \\
\hline Cholesterol $^{\mathrm{b}}$ & 20 \\
\hline Lecithin & 10 \\
\hline Sodium alginate & 37 \\
\hline$V$ itamin premix ${ }^{c}$ & 20 \\
\hline Mineral premix ${ }^{d}$ & 3 \\
\hline Proximate composition & $\%$ \\
\hline Crude protein & $47.9 \pm 0.594$ \\
\hline Total lipids & $10.4 \pm 1.591$ \\
\hline Moisture & $6.8 \pm 0.761$ \\
\hline Ash & $4.8 \pm 1.220$ \\
\hline
\end{tabular}

${ }^{a}$ Research Organics Inc. USA

${ }^{\mathrm{b}}$ Berna, Argentina

${ }^{\mathrm{c}}$ vitamin premix without vitamin $\mathrm{A}$ acetate $\left(\mathrm{mg} \mathrm{kg}^{-1}\right)$ : cholecalciferol 35 ; thiamin 163; rivoflavin 156; pyridoxine 213 ; calcium pantothenate 250; biotin 250; niacin 500; folic acid 25; $\mathrm{B}_{12}$ HCL 20; ascorbic acid Rovimix STAY C 781; menadione 34; inositol 300; choline chloride $200 ; \alpha$ tocopherol acetate 1,500 wheat semolina csp; cellulose was replaced by appropriate amounts of Rovimix A 500 in the premix to give different levels of vitamin A (Roche, Argentina)

${ }^{\mathrm{d}}$ mineral premix: calcium 1,000 mg; magnesium $500 \mathrm{mg}$; potassium 99 $\mathrm{mg}$; zinc $30 \mathrm{mg}$; $10 \mathrm{mg}$; iron $10 \mathrm{mg}$; copper $2 \mathrm{mg}$; iodine $150 \mu \mathrm{g}$; selenium $200 \mu \mathrm{g}$; chromium $200 \mu \mathrm{g}$; molybdenum $500 \mu \mathrm{g}$ (Twin laboratories, Inc. USA)

Mean of three replicates \pm standard deviation

The water temperature varied between 17 and $22^{\circ} \mathrm{C}$, salinity was $34 \mathrm{~g} \mathrm{~L}^{-1}$ and $\mathrm{pH} 6.5$. Initial feeding was $5 \%$ of the biomass in each aquarium. Daily, the amount of food was adjusted to the shrimp requirements, and exuviae and dead individuals were recorded.

At the end of the experiment, shrimp from each aquarium were counted and weighed. Samples of individuals at the same treatment, in intermolt stage (Díaz
\& Petriella 1990) were immediately pooled and frozen for freeze drying. Dried hepatopancreas were homogenized in chilled distilled water and centrifuged for $30 \mathrm{~min}$ at $10000 \mathrm{~g}$ and at $4^{\circ} \mathrm{C}$. Lipids were eliminated and the soluble protein was evaluated in the supernatants (Bradford 1976), with albumin from chicken egg white (Sigma) as the standard.

Proteinase activity was measured kinetically utilizing chromogenic substrate. The substrate $1 \%$ azocasein was dissolved in the $7.5 \mathrm{pH}$ buffer solutions (FernándezGimenez et al. 2001). Triplicates of $5 \mu \mathrm{L}$ of enzyme extracts were mixed with $0.5 \mathrm{~mL}$ of buffer and $0.5 \mathrm{~mL}$ of substrate solution. The reaction mixtures were incubated for $10 \mathrm{~min}$ at $25^{\circ} \mathrm{C}$. Proteolysis was stopped by adding $0.5 \mathrm{~mL}$ of $20 \%$ trichloroacetic acid TCA, and the mixture was centrifuged in Eppendorf tubes for $5 \mathrm{~min}$ at 14000 $g$. The supernatants were separated from the undigested substrate and the absorbance at $366 \mathrm{~nm}$ was recorded with a spectrophotometer (Shimadzu UV-2102 PC, UV-visible Scanning Spectrophotometer) for the released dye (García-Carreño 1992).

At the end of the experiment, six individuals of each treatment in intermolt stage were selected for histological studies. Hepatopancreas were fixed in Davidson's fixative (distilled water, ethanol, formaldehyde, acetic acid) for $24 \mathrm{~h}$, embedded in paraffin, and tissue sections were cut to approximately $5 \mu \mathrm{m}$ and stained with haematoxylin and eosin (Bell \& Lightner 1988).

Diets were analyzed for ash $\left(550^{\circ} \mathrm{C}\right)$ and dry matter $\left(60^{\circ} \mathrm{C}\right)$. Total protein was estimated by the micro-Kjeldahl method (Barnes 1959), and total lipids were determined using the Soxhlet method (IRAM 1985).

The following statistical analyses at 0.05 level of significance (Sokal \& Rohlf 1995) were performed: Cochran or Bartlett, ANOVA and Student's $t$-test were used to find differences among means, and chi-square test was applied to assess differences in percentage survival.

\section{Results}

At the end of the experiment, the percentage of weight gain of shrimp fed various diets ranged from 45 to $73 \%$ in all treatments, with no significant differences among them. Survival was between 62 and $95 \%$, and there were significant differences between controls (squid and vitamin free diet) and the other treatments (Table 2).

Shrimp fed with $140 \mathrm{mg}$ (Fig 2) and $160 \mathrm{mg}$ Vitamin $\mathrm{A} \mathrm{kg}^{-1}$ diet exhibited some histopathological changes in the hepatopancreas, such as cellular hyperplasia and hypertrophy, disorganized tissue, and shrinkage of cells. These alterations are common signs of malnutrition. 
Table 2

Weight gain and survival of juveniles fed different diets

Incremento en peso y supervivencia de los juveniles alimentados con las diferentes dietas

\begin{tabular}{|c|c|c|c|c|}
\hline \multirow[t]{2}{*}{$\operatorname{Diet}^{a}$} & \multicolumn{2}{|c|}{ Mean weight $(\mathrm{g})^{\mathrm{b}}$} & \multirow[t]{2}{*}{$\% \Delta \mathrm{w}$} & \multirow[t]{2}{*}{$\% \mathrm{~S}$} \\
\hline & Initial & Final & & \\
\hline $\mathrm{C}$ (squid mantle) & $1.0 \pm 0.03$ & $1.7 \pm 0.51$ & 59 & $62^{\mathrm{a}}$ \\
\hline Vitamin free & $1.0 \pm 0.27$ & $1.4 \pm 0.35$ & 45 & $62^{\mathrm{a}}$ \\
\hline 140 & $1.1 \pm 0.38$ & $1.7 \pm 0.69$ & 57 & $86^{\mathrm{b}}$ \\
\hline 160 & $1.0 \pm 0.32$ & $1.7 \pm 0.67$ & 73 & $67^{\mathrm{b}}$ \\
\hline 180 & $1.0 \pm 0.33$ & $1.7 \pm 0.65$ & 69 & $95^{\mathrm{b}}$ \\
\hline
\end{tabular}

${ }^{a}$ mg vitamin $\mathrm{A} \mathrm{kg}^{-1}$ diet

${ }^{\mathrm{b}}$ Values are means \pm standard error of triplicates.

$\% \Delta \mathrm{w}$ : percentage in mean weight; $\% \mathrm{~S}$ : survival.

Percentages with similar superscripts are not significantly different $(P<0.05)$

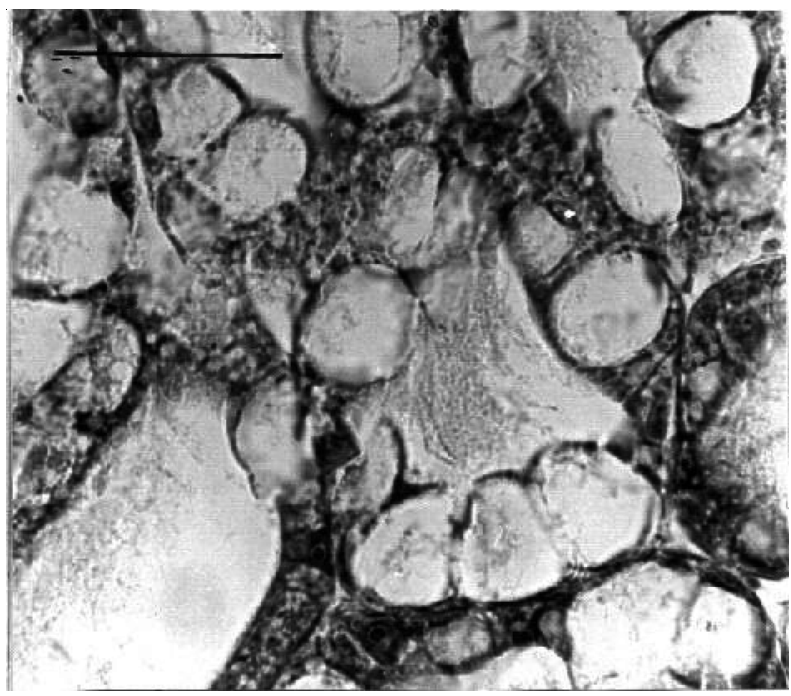

Figure 2

Hepatopancreas of $P$. muelleri fed a diet with $140 \mathrm{mg} \mathrm{kg}^{-1}$ : transverse section through a tubules, showing disorganized tissue with hypertrophy and shrinkage of cells. Bar $=\mathbf{5 0} \mu \mathrm{m}$

Hepatopáncreas de P. muelleri alimentados con una dieta con $140 \mathrm{mg} \mathrm{kg}^{-1}$ : corte transversal de un túbulo que muestra el tejido desorganizado con hipertrofia y retracción celular. Barra $=50 \mu \mathrm{m}$
Desquamation of epithelial cells was observed at the basal region. Folding of the basement membrane surrounding the tubular digestive epithelium was observed. Individuals fed with squid mantle and $180 \mathrm{mg} \mathrm{kg}^{-1}$ did not reveal any pathology in the organ, showing a normal structure in all cases (Fig. 3).

Histological analysis of the hepatopancreas of shrimp fed vitamin free diet showed cells with unclear nuclear and cellular contours. Different cell types could not be recognized, and the brush border was disrupted in most of cells (Fig. 4).

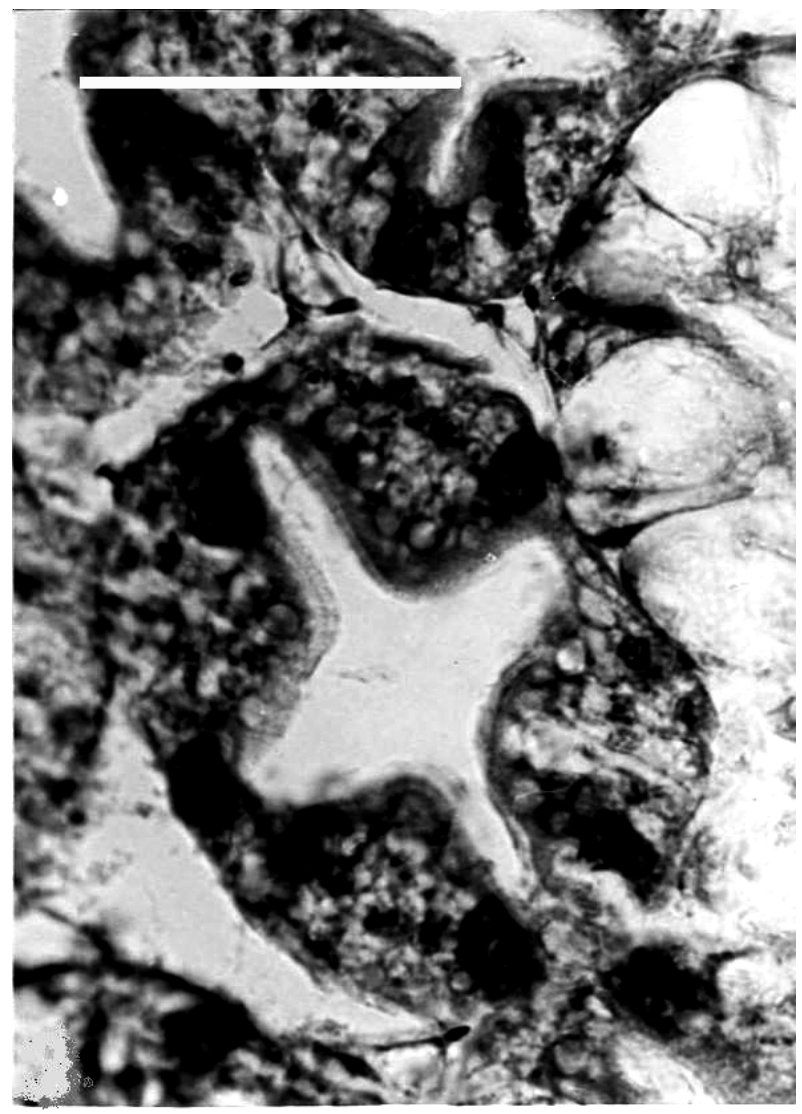

Figure 3

Hepatopancreas of $P$. muelleri fed a diet with $180 \mathrm{mg} \mathrm{kg}^{-1}$ : transverse section through a tubule, showing the cellular types, similar to those of wild prawns. Bar $=50 \mu \mathrm{m}$

Hepatopáncreas de $P$. muelleri alimentados con una dieta con $180 \mathrm{mg} \mathrm{kg}^{-1}$ : corte transversal de un túbulo que muestra los tipos celulares similar al salvaje.

Barra $=50 \mu \mathrm{m}$ 


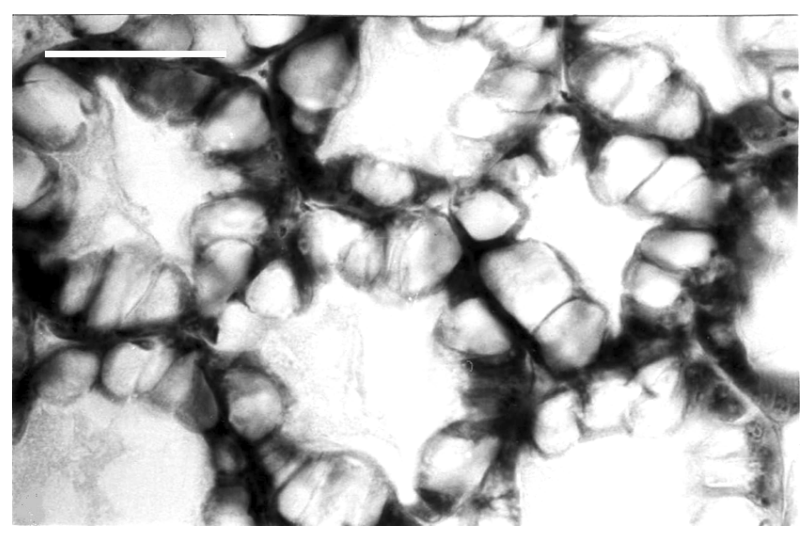

Figure 4

Hepatopancreas of $\boldsymbol{P}$. muelleri fed a vitamin free diet: transverse section through a tubule revealed severe cytological alterations. Note complete loss or destruction of epithelial cells and scarce intertubular space. Bar $=25 \mu \mathrm{m}$

Hepatopáncreas de P. muelleri alimentado con una dieta libre de vitaminas: corte transversal de un túbulo que muestra alteraciones citológicas severas. Se observa la destrucción completa o pérdida de las células epiteliales y escaso espacio intertubular. Barra $=25 \mu \mathrm{m}$

Table 3

Protein content and specific activity in enzyme extracts from Pleoticus muelleri

Contenido proteico y actividad enzimática de los extractos de Pleoticus muelleri

\begin{tabular}{ccc}
\hline & $\begin{array}{c}\text { Protein content } \\
\left(\mathrm{mg} \mathrm{mL}^{-1}\right)\end{array}$ & $\begin{array}{c}\text { Specific activity } \\
\left(\mathrm{abs} \mathrm{min}^{-1} \mathrm{mg}^{-1} \text { protein }\right)\end{array}$ \\
\hline Wild $^{*}$ & $7.37^{\mathrm{a}}$ & $0.63^{\mathrm{a}}$ \\
C (squid mantle) & $5.56^{\mathrm{a}}$ & $0.78^{\mathrm{a}}$ \\
Vitamin free & $4.60^{\mathrm{a}}$ & $0.11^{\mathrm{b}}$ \\
$140^{* *}$ & $7.12^{\mathrm{a}}$ & $1.15^{\mathrm{a}}$ \\
$160^{* *}$ & $13.08^{\mathrm{a}}$ & $0.67^{\mathrm{a}}$ \\
$180^{* *}$ & $14.30^{\mathrm{a}}$ & $0.37^{\mathrm{b}}$ \\
\hline
\end{tabular}

Similar superscripts are not significantly different $(P<0.05)$.

*Fernández Gimenez et al. (2001).

**mg vitamin $\mathrm{A} \mathrm{kg}^{-1}$ diet

Table 3 shows the protein content and the specific activities of proteinases in the hepatopancreas of juveniles fed with different diets. There were no differences in the protein content of hepatopancreas. Proteinase activity with azocasein as substrate varied among treatments; the highest activity was recorded with diets 140 and $160 \mathrm{mg}$ vitamin $\mathrm{A} \mathrm{kg}^{-1}$ and a significant decrease was observed with $180 \mathrm{mg} \mathrm{kg}^{-1}$.

\section{Discussion}

According to the present results it seems there is no relation between percent weight gain-survival and the level of vitamin A in diets, under these experimental conditions. The percent weight gains obtained in these experiments were similar to the values previously found for this species (Müller et al. 1986, Harán \& Fenucci 1997, Díaz et al. 1999).

Otherwise, He et al. (1992) demonstrated that vitamin A deficiency in diets of Litopenaeus vannamei (Boone, 1931) has deleterious effects on growth, but it does not affect shrimp survival. Fenneropenaeus chinensis (Osbeck, 1765) larvae showed poor survival when fed diets deficient in vitamin A (Liang \& Ji 1998).

The histopathology of the experimental shrimp indicates degenerative changes in the hepatopancreas related to low levels of vitamin A in diets. Variations in the cytological characteristics of the hepatopancreas induced by sub-optimal diets and starvation have been reported for other crustaceans. The most notable changes were shrinkage of cells and microvilli as well as condensation of nuclear chromatin (Icely \& Nott 1992); such characteristics are considered signs of malnourishment (Rodriguez-Souza et al. 1996).

In the present work, changes in hepatopancreatic cell morphology were evident in individuals fed different diets. The hepatopancreas from individuals fed squid mantle did not reveal any pathology, showing a normal structure. In previous studies with $P$. muelleri similar results were obtained when feeding squid mantle (Cuartas et al. 2003, Díaz \& Fenucci 2002). Shrimp fed diet vitamins free, 140, and $160 \mathrm{mg}$ vitamin $\mathrm{A} \mathrm{kg}^{-1}$, manifested severe pathology in the hepatopancreatic structure.

Histological results of these experiments are supported by several studies carried out with others penaeids. Reddy et al. (1999a, 1999b) observed in Penaeus monodon Fabricius, 1798 and Fenneropenaeus indicus (H. Milne Edwards, 1837), that diets deficient in vitamin A resulted in histopathological changes in the digestive gland with detachment or destruction of the epithelial cells.

Penaeus monodon fed diets without water soluble vitamins showed no significant differences in survival rates, but it showed poor weight gain and severe midgut pathology, such as necrosis and detachment of the epithelial cells. Severe cases were found in treatments without vitamin supplementation, in which inositol, 
choline or vitamin $\mathrm{C}$ was eliminated from the diets (Catacutan \& De la Cruz 1989, Chen 1993).

Based on histopathological changes in the hepatopancreas cells, the requirement of Pleoticus muelleri appears to be $180 \mathrm{mg}$ Vitamin $\mathrm{A} \mathrm{kg}^{-1}$. Likewise, He et al. (1992) determined that the minimum dietary vitamin A requirement of $L$. vannamei juveniles was 130 $\mathrm{mg} \mathrm{kg}^{-1}\left(2,600 \mathrm{IU} \mathrm{kg}^{-1}\right)$, based on shrimp growth. This level represents a $50 \%$ reduction in the amount recommended by Akiyama et al. (1992) for commercial diets.

Pangantihon-Kuhlmann et al. (1998) suggested that 20,000 IU vitamin $\mathrm{A} \mathrm{kg}^{-1}$ diet is needed for inclusion in broodstock diets of Penaeus monodon. Otherwise, 40$60 \mathrm{mg} \mathrm{kg}^{-1}$ promotes good survival and health of $F$. chinensis larvae (Liang \& Ji 1998). All these results suggest an important variation in the vitamin A requirements among different species.

Crustacean penaeids can adapt quite well to changes in diet composition by the induction of digestive enzymes synthesized and secreted in the hepatopancreas (Le Moullac et al. 1997). These digestive enzymes hydrolyze a variety of substrates, and various factors are involved in their regulation, such as, ontogenetic changes (Lovett \& Felder 1990), body size (Lee \& Lawrence 1985), circadian rhythms (Molina et al. 2000), and molting stage (Fernández-Gimenez et al. 2001, 2002).

Several authors have shown that different protein levels in the diet affect the growth rate, survival and digestive enzyme activities in penaeoid shrimp (Lee \& Lawrence 1985, Kumlu \& Jones 1995, Gamboa-Delgado et al. 2003). Our study showed a decrease in the specific activity of the hepatopancreas enzymes in Pleoticus muelleri fed with $180 \mathrm{mg} \mathrm{kg}^{-1}$ diet. Nevertheless individuals fed with the other diets $\left(140 ; 160 \mathrm{mg} \mathrm{kg}^{-1}\right)$ possess an enzymatic activity similar to that of wild shrimp (Fernández-Gimenez et al. 2001). The lack of correlation between growth and protease activity in these studies suggests that protease activity is affected by vitamin A level. This vitamin is required for the maintenance of the gastro-intestinal tract due to its participation in the formation of mucopolysaccharides and for the release of proteolytic enzymes from lysosomes (Tacon 1991).

There is a tendency to assume that the vitamin levels identifies by various researchers from laboratory investigations are a reasonable approximation of requirements. Eventually these enhanced levels became the basis of new standard formulations. In semi-intensive cultivation of species of shrimp the need for a vitamin supplement is difficult to establish, Dall (1995) suggests that vitamin A supplementation is unnecessary when fish oil and carotenoid are added to penaeid diets. However it is advisable to add a vitamin mix which contains the most stable form of each vitamin to feeds used in intensive cultivation (Houser \& Akiyama 1999).

This study indicates that vitamin A in purified diets is essential to maintain the normal morphology and function of Pleoticus muelleri hepatopancreas. The enzymatic activity of the organ was similar to that observed in wild shrimp of the same species ( 0.36 to $0.63 \mathrm{abs} \mathrm{min}{ }^{-1} \mathrm{mg}^{-1}$ ) (Fernández-Gimenez et al. 2001), the organ evidences that it can also maintain its functionality with suboptimal diets. In summary, the optimal vitamin A requirement for P. muelleri, under the present experimental conditions seems to be $180 \mathrm{mg} \mathrm{kg}^{-1}$.

\section{Acknowledgments}

The authors wish to express their gratitude to Mr. JC Carrizo (INIDEP) for supplying free fatty acids. This research was funded by PICT 20209 of Agencia Nacional de Promoción Científica y Tecnológica (Argentina). The authors also thank anonymous reviewers and Editor for critically reviewing the manuscript.

\section{Literature cited}

Akiyama DM, WG Dominy \& AL Lawrence. 1991. Penaeid shrimp nutrition for the commercial feed industry. In: Akiyama DM \& RKH Tan (eds). Proceedings of Aquaculture Feed Processing and Nutrition Workshop, pp. 80-98. American Soybean Association, Singapore.

Akiyama DM, WG Dominy \& AL Lawrence. 1992. Penaeid shrimp nutrition. In: Fast EW \& LJ Lester (eds). Marine Shrimp Culture: Principles and Practices, pp. 198-211. Elsevier Science Publishers, Amsterdan.

Barnes H. 1959. Apparatus and methods of oceanography, 341 pp. George Allen \& Unwin, New York.

Bell TA \& DV Lightner. 1988. A handbook of normal penaeid shrimp histology, 114 pp. Allen Press, Lawrence.

Boschi EE. 1972. El acuario de agua salada. Contribución Instituto Biología Marina, Mar del Plata 220: 213-213.

Boschi EE. 1986. La pesquería del langostino del litoral patagónico. Cuadernos de Redes, Buenos Aires 20: 1-8.

Bradford MM. 1976. A rapid and sensitive method for the quantification of microgram quantities of protein utilizing the principle of protein dye binding. Analytical Biochemistry 72: 248-254.

Catacutan MR \& M De la Cruz. 1989. Growth and mid-gut cells profile of Penaeus monodon juveniles fed water soluble vitamin deficient diets. Aquaculture 81: 137-144.

Ceccaldi HJ. 1997. Anatomy and physiology of the digestive system. In: D’Abramo LR, DE Conklin \& DM Akiyama 
(eds). Crustacean Nutrition Advances in World Aquaculture 6: 261-291. World Aquaculture Society, Louisiana.

Chen HY. 1993. Recent advances in nutrition of Penaeus monodon. Journal of the World Aquaculture Society 24(2): 231-240.

Conklin DE. 1997. Vitamins. In: D'Abramo LR, DE Conklin \& DM Akiyama (eds). Crustacean Nutrition Advances in World Aquaculture 6: 123-149. World Aquaculture Society, New Orleans.

Cuartas EI, AC Díaz \& AM Petriella. 2002. Estudio morfológico y funcional del hepatopáncreas del langostino Pleoticus muelleri Bate (Crustacea, Penaeoidea). Revista de Investigación y Desarrollo Pesquero 15: 5-13.

Cuartas EI, AC Díaz \& AM Petriella. 2003. Modificaciones del hepatopáncreas del langostino Pleoticus muelleri (Crustacea, Penaeoidea) por efecto de la salinidad. Biociencias 11(1): 53-59.

Dall W. 1995. Carotenoids versus retinoids (Vitamin A) as essential growth factors in penaeid prawns (Penaeus semisulcatus). Marine Biology 124: 209-213.

Díaz AC \& JL Fenucci. 2002. Comparative evaluation of different animal protein source in juveniles of Pleoticus muelleri (Crustacea, Penaeoidea). In: Escobar-Briones E \& F Alvarez (eds). Modern Approaches to the study of crustacean, pp.75-78. Kluwer Academic Plenum Publishers, New York.

Díaz AC \& AM Petriella. 1990. Moult staging in the shrimp, Pleoticus muelleri Bate. Journal of Aquaculture in the Tropics 5: 181-189.

Díaz AC, AV Fernández-Gimenez \& JL Fenucci. 1999. Evaluación del extracto proteico de calamar en la nutrición del langostino argentino Pleoticus muelleri Bate (Decapoda, Penaeoidea). In: Cabrera T., Jory D. \& Silva M. (eds). Memorias Acuicultura '99, pp. 184-192. World Aquaculture Society, Puerto La Cruz.

FAO. Food and Agriculture Organization of the United Nations. http://www.fao.org. [consulted xxx]

Fenucci JL \& ZP Zein-Eldin. 1976. Evaluation of squid mantle meal as a protein source in penaeid nutrition. In: Pillay TVR \& WA Dill (eds). FAO Technical Conference on Aquaculture, Kyoto, pp. 601-605. Fishing News Books, Farnham.

Fenucci JL, MI Müller \& JH Magnaterra. 1990. Factibilidad de cría del langostino (Pleoticus muelleri). Frente Marítimo 7(B): 103-108.

Fernández-Gimenez AV, FL García-Carreño, MA Navarrete del Toro \& JL Fenucci. 2001. Digestive proteinases of red shrimp Pleoticus muelleri (Decapoda, Penaeoidea): partial characterization and relationship with molting. Comparative Biochemistry and Physiology 130(B): 331338.

Fernández-Gimenez AV, FL García-Carreño, MA Navarrete del Toro \& JL Fenucci. 2002. Digestive proteinases of Artemesia longinaris (Decapoda, Penaeidae): partial characterization and relationship with molting. Comparative Biochemistry and Physiology 132(B): 593-598.

Gamboa-Delgado J, C Molina-Poveda \& C Cahu. 2003. Digestive enzyme activity and food ingesta in juvenile shrimp Litopenaeus vannamei (Boone, 1931) as a function of body weight. Aquaculture Research 34: 1403-1411.

García-Carreño FL. 1992. The digestive proteases of langostilla (Pleuroncodes planipes, Decapoda): their partial characterization, and the effect of feed on their composition. Comparative Biochemistry and Physiology 103B(3): 575578.

Harán NS \& JL Fenucci. 1997. Acción de ácidos grasos dietarios sobre el crecimiento del langostino argentino Pleoticus muelleri Bate. Revista de Investigaciones Marinas 18(2): 155-161.

He H, AL Lawrence \& R Liu. 1992. Evaluation of dietary essentiality of fat-soluble vitamins, A, D, E and K for penaeid shrimp Penaeus vannamei. Aquaculture 103: 177185.

Houser RH \& DM Akiyama. 1997. Feed formulation principles. In: D'Abramo LR, DE Conklin \& DMAkiyama. Crustacean Nutrition. Advances in World Aquaculture 6: 493-519.

Icely JD \& JA Nott. 1992. Digestion and absorption: digestive system and associated organs. In: Harrison FW \& AG Humes (eds). Microscopic Anatomy of Invertebrates 10: 147-202. Wiley-Liss, New York.

IRAM. 1985. Método de determinación de la materia grasa por la técnica de extracción en un aparato tipo Soxhlet o Twiselmann. Instituto Argentino de Racionalización de Materiales, Norma IRAM 15040 1: 1-7.

Kumlu M \& DA Jones. 1995. The effect of live and artificial diets on growth, survival and trypsin activity in larvae of Penaeus indicus. Journal of the World Aquaculture Society 26(4): 406-415.

Lee PG \& AL Lawrence. 1985. Effects of diet and size on growth, feed digestibility and digestive enzyme activities of the marine shrimp, Penaeus setiferus Linnaeus. Journal of World Mariculture Society 16: 275-287.

Le Moullac G, B Klein, D Sellos \& A van Wormhoudt. 1997. Adaptation of trypsin, chymotrypsin and a-amylase to casein level and protein source in Penaeus vannamei (Crustacea, Decapoda). Journal of Experimental Marine Biology and Ecology 208: 107-125.

Liang M \& W Ji. 1998. Study on nutritional requirement of vitamin A for Chinese prawn Penaeus chinensis larva. Marine Fisheries Resources 19(1): 86-90.

Liñán-Cabello MA, J Paniagua-Michel \& PM Hopkins. 2002. Bioactives roles of carotenoids and retinoids in crustaceans. Aquaculture Nutrition 8: 299-309.

Lovett DL \& DL Felder. 1990. Ontogenic change in digestive enzyme activity of larval and postlarval white shrimp Penaeus setiferus (Crustacea, Decapoda, Penaeidae). The Biological Bulletin 178: 144-159. 
Mallo JC, JL Fenucci \& CM Galarza 1999. Cría masiva de larvas y postlarvas del langostino argentino Pleoticus muelleri Bate (Crustacea, Decapoda, Solenoceridae). In: Cabrera T, D Jory \& M Silva (eds). Memorias Acuicultura '99, pp. 313-317. World Aquaculture Society, Puerto La Cruz.

Molina C, E Cadena \& F Orellana. 2000. Alimentación de camarones en relación a la actividad enzimática como respuesta natural al ritmo circadiano y ciclo de muda. In: Cruz-Suarez LE, D Ricque-Marie, M Tapia-Salazar, MA Olvera-Novoa \& R Civera-Cerecedo (eds), Proceedings of V Simposium Internacional de Nutrición Acuícola, pp. 358380, Mérida.

Müller MI, JL Fenucci \& JH Magnaterra. 1986. Estudio sobre la influencia de diversas condiciones ambientales en el crecimiento y supervivencia de Artemesia longinaris Bate (Decapoda, Penaeidae). Revista Latinoamericana de Acuicultura 28: 7-13.

Pangantihon-Kuhlmann MP, O Millamena \& Y Chern. 1998. Effect of dietary astaxanthin and vitamin A on the reproductive performance of Penaeus monodon broodstock. Aquatic Living Resources 11(6): 403-409.
Poston HA. 1986. Vitamin requirements of finfishes: A review. Information Service Animal Nutrition Department, pp. 136. Roche/U.S. Fish and Wildlife Service, New York.

Reddy HRV, MG Naik \& TS Annappaswamy. 1999a. Evaluation of the essentiality of vitamins for Penaeus monodon. Aquaculture Nutrition 5(4): 267-275.

Reddy HRV, A Rai \& TS Annappaswamy. 1999b. Essential vitamins for juvenile white shrimp, Penaeus indicus. Israeli Journal of Aquaculture 51(3): 122-133.

Rodriguez-Souza JC, S Sekine, S Suzuki, Y Shima, CA Strüssmann \& F Takashima. 1996. Usefulness of histological criteria for assessing the adequacy of diets for Panulirus japonicus phyllosoma larvae. Aquaculture Nutrition 2: 133-140.

Sokal RR \& FJ Rohlf. 1995. Biometry, the principles and practice of statistics in biological research, $887 \mathrm{pp}$. WH Freeman, New York.

Tacon AGJ. 1991. Vitamin nutrition in shrimp and fish. In: Akiyama DM \& RKH Tan (eds). Proceedings of Aquaculture Feed Processing and Nutrition Workshop, pp. 10-41. American Soybean Association, Singapore.

Recibido el 9 de enero de 2008, aceptado el 29 de julio de 2008 